\title{
Towards Reclaiming the Colonised Mind: The Liberating Fantasies of Duiker and Ihimaera
}

\author{
Molly Brown
}

\begin{abstract}
Ursula le Guin once observed that 'the story - from Rumpelstiltskin to War and peace -is one of the basic tools invented by the human mind, for the purpose of gaining understanding' and that while 'there have been great societies that did not use the wheel... there have been no societies that did not tell stories'(1989,p.27). By comparing the story to the wheel, she gently reminds the technologyobsessed reader that verbal structures have as much, if not more, to offer our world than mechanical ones and that while one tells or listens to stories one is not merely taking part in an idle entertainment but performing an action with vital and potentially transformative functions.
\end{abstract}

Within the range of stories available to children, fantasy has, of course, a unique position in that, as Bruno Bettelheim observes:

Through most of man's [sic] history, a child's
intellectuallife, apart from immediate experiences
within the family, depended on mythical and
religious stories and onfairytales. Thistraditional
literaturefed the child'simagination andstimulated
hisfantasizing. Simultaneously, since thesestories
answered the child'smostimportant questions, they
were a major agent of his socialization. $(1976$, p.24)

We live in an increasingly secular world in which the dominant myths of many societies can no longer answer the questions of the young with the untroubled authority imagined by Bettelheim. This is perhaps especially true in countries in which processes of colonisation have marginalised and devalued indigenous mythologies. The rapid cultural change forced on such societies militates against the preservation of cultural identity and may lead both parents and therefore children to see their own language and stories as unnecessary encumbrances, embarrassing relics of a way of life at odds with global criteria for success.

Deprived of their narrative birthright, children in colonial and postcolonial societies are then forced to look for the answers they need in stories uneasily transplanted from very distant and different environments. However, such attempts are rarely fully satisfying since, as Neil Gaiman wryly demonstrates in his satirical fantasy American Gods
(2005), mythical beings do not usually take kindly to being uprooted and tend to become faded or distorted versions of themselves when forced to migrate with their worshippers to new and spiritually uncongenial surroundings.

Cultural dissonances of this kind are perhaps less problematic in works of fantasy aimed at younger readers. Lutz Rohrich claims that 'the fact that folk narratives appear among so many peoples in such similar forms and ways shows that they have a common meaning which transcends language barriers' (In McGlathery 1988, p.12) and this view seems to be supported by both Propp's syntagmatic readings of Russian folklore, which led him to claim that the number of functions known to the fairy tale is limited' (1979, p.21), and Luthi's theory that the defining characteristic of folk tales is their abstract style. In contrast to myths, legends and sagas, Luthi argues that the folk tale does not attempt to create settings reflective of the real world. Instead, he suggests that such a tale 'transforms the world; it puts a spell on its elements and gives them a different form, and thus it creates a world with a distinct character of its own' (1986, p.24).

Fantasy for older children, however, is rarely quite as self sufficient. Since the end of the nineteenth century it has tended rather to weave magic into the tapestry of everyday experience so that a Psammead may be found in an abandoned gravel pit (Nesbit 1979, p.20) and subtle knives can be used to cut doorways from contemporary Oxford into a dazzling variety of alternative universes (Pullman 1998). Tweens and teens are vigorously engaged with their environment and look to fantasy not for simple escapism but for creative reworkings of inherited folklore, ways to make connections between the cultural archetypes transmitted by myth and folk tale and the daily anxieties and choices of adolescence. Francis Spufford expresses this need beautifully in his memoir The Child that Books Built:

The books that I loved best were... the ones that started in this world and then took you to another. Earthsea and Middle Earth were separate. You traveled in them in imagination as you read Le Guin and Tolkien, but they had no location in relation to this world. Their richness did not call to you at home in any way. It did not lie just beyond a 
threshold in this world that you might find if you were particularly lucky, or particularly blessed. I wanted there to be doors.

(Spufford 2002, p.85)

In fact, Brian Attebery claims that of all the subgenres to emerge within fantasy in recent years it is such dooropening fantasies, which he also claims have yet to be adequately named, that promise to 'reshape the genre most significantly' (1992, p.126).

J.K. Rowlings's Harry Potter series clearly belongs to this category and has done much to reinvigorate global interest in fantasy as is demonstrated by its astonishing global sales. More than sixty million copies of the first six books in the series had been sold even prior to the record-breaking release of the final volume Harry Potter and the deathly hallows in July 2007. Yet, on the weekend when Harry Potter and the deathly hallows was released, the estimated total South African sales for all the books in the series stood at only about 150000 . While this figure is high in South African terms, it is surprisingly low in comparison with other countries. For instance, in Australia, which has approximately half the population of South Africa, about 4.5 million copies of books in the series had already been sold (Rossouw 2007, p.9).

Rehana Rossouw, the editor of The Weekender, a leading South African Saturday paper, has considered this discrepancy in an editorial in which she suggests that perhaps the extrapolated references that 'first-world kids would recognize instantly are outside of the average South African child's experience'(Rossouw 2007,p.9). Certainly some element of recognition is needed to evoke a response to fictional worlds and thus fantasists, including Rowling, often allude to European fairy tale and romance conventions creating a 'simplified version of the middle ages' so as to 'rehistoricize fantastic assertions by placing them within an approximation of the most accessible milieu in which such statements could have been made within the discourse of reporting' (Attebery 1992, p.132). When this populist medievalism is alien to the culture of the child reading the fantasy, as it is to the majority of South African children, it becomes unsurprising that such a child should be unable to find a point of entry into the genre.
It seems obvious then that children from traditional African or Australasian cultures might find it easier to gain access to fantasy were it to use more familiar cultural tropes. Yet the heightened racial sensibilities characterising postcolonial societies also complicate attempts to use indigenous myths within fantasy novels for older readers. Since, until recently, writers from colonised cultures were both limited in their access to the means of modern book production and unfamiliar with dominant fictional conventions, writers producing fantasy for nine-to-twelve-year-olds have tended to come from culturally-privileged groups. Because of this, any attempt to rework local myths has made such writers vulnerable to charges of literary colonialism, the forcible seizure of tropes and figures belonging by right to others.

How then can fantasy be used to reclaim rather than further subjugate colonised minds? Homi Bhabha suggests that the 'non-synchronous temporality of global and national cultures opens up a cultural space - a third space - where the negotiation of incommensurable differences creates a tension peculiar to borderline existences'(1994,p.218) and that the boundary may thus become 'the place from which something begins its presencing'(1994,p.5). Interestingly, in both South Africa and New Zealand, writers who inhabit precisely this liminal creative space seem to be beginning to rework the conventions of children's fantasy in challenging and affirming ways.

Witi Ihimaera was born to Maori parents in 1944 in a period when, as Corbalis and Garnett observe:

On the one hand, the community of which he was part was predominantly a Maori one, and many traditional customs were still a day-to day part of Maori life. On the other hand, the 'official'view of Maoritanga in the schools, and to a certain extent among the Maori people themselves, was that such traditional customs, and especially the use of the Maori language, were to be discouraged because they were no longer appropriate or useful in the modern world.

(1984, p.8)

Distanced by ethnicity from New Zealand's dominant literary culture, Ihimaera also began to be distanced from his 
Maori roots first by his education, repressed homosexuality and marriage to a pakeha, Jane Cleghorn, and then by a period spent living in London where he says he was able to write more easily because he was 'far enough removed from reality and Maori life...to be able to sit and look at it objectively' (In Corbalis and Garnett 1984, p.12). During his time in London, he wrote the short story collection Pounamu pounamu (1972) and the first drafts of two novels: Tangi (1973) and Whanau (1974). Their publication made him the first Maori writer to publish both a book of short stories and a novel. After publishing a more overtly political collection of short stories, The New Net Goes Fishing (1977), he decided to stop writing since his fiction's initial purpose, 'to establish and describe the emotional landscape of the Maori people', suddenly seemed to him less important than describing 'the political and social reality' (Corbalis and Garnett, 1987, p.255).

Nearly ten years later, he returned to print with The Matriarch (1986), followed in 1987 by a book, which has been very popular with younger readers, The Whale Rider, a fantasy work about a young Maori girl, Kahu, who, although initially rejected by her traditional grandfather, eventually demonstrates that she alone can reconnect the tribe to its ancestral life force embodied totemically in the beached whale or tipua whom she rescues. Nicky Caro's 2002 film version of this novel which starred Keisha Castle-Hughes won widespread acclaim and did much to popularise the book on which it was based.

Significantly, the only truly powerful fantasy written in English and aimed at older children to have come out of South Africa thus far was also written by a man who, like Witi Ihimaera, inhabited the creative littoral zone between coloniser and colonised. K. Sello Duiker, a black South African, spent his formative years in Britain before returning home to study journalism at Rhodes University, a traditionally white institution. Duiker won the Commonwealth Prize for a first novel in the Africa region for his novel, Thirteen Cents (2000), a brutally realistic depiction of the lives of Cape Town street children, and the Herman Charles Bosman prize for English Literature for his second novel, The Quiet Violence of Dreams (2001), which explores the life of a traumatised and drug-addicted young man trying to come to terms both with his homosexuality and, in Duiker's own words, with 'what it means to be black and educated' (in Dunston 2001, p.13).

A four year gap followed in which Duiker, like Ihimaera, struggled to find meaning in the act of writing in a society warped by social inequality. During this time he admitted that he was trying to write a novel for children and that he was finding that reaching younger readers was something of a challenge (in Mzamane 2005, p.24). Sadly, unlike Ihimaera, Duiker finally found himself utterly unable to come to terms with either his ambivalent sexuality or his creative gifts. After his tragic suicide in January 2005, the manuscript of his fantasy novel was found in his desk and subsequently edited and published by a close friend, Annari van der Merwe.

The Hidden Star seems, initially at least, to be entirely different from the novels which preceded it in that, while it is clearly a work written for children, it moves away from the gritty realism that characterises Duiker's earlier works in favour of a world in which ancestral spirits offer hope and guidance to a young girl who finds a magic stone. Nolitye, whose name means woman of the stone, lives with her hawker mother in Phola, a poor African township on the fringes of Johannesburg. She soon learns that her stone is merely a fragment of a greater whole and that her task is to gather together its scattered pieces and reunite them in order to prevent the dissolution of her world. Nolitye is helped in her task by not only by Nomakhosi, the spirit of the stone, but also by her friends Bheki and Four Eyes and a pack of stray dogs whose language she can understand. Eventually she confronts and defeats both her bullying schoolmate, Rotten Nellie, and Ncityana, the unmaker, and all his terrifying servants from the sorceress, MaMtonga, to the ferocious indawas, shaggy creatures with knife-like teeth. By her courage, she rescues her imprisoned father and reawakens the dormant spirituality of her people.

In these two fantasies, Duiker and Ihimaera consciously foreground the evocative details of life in the communities from which their young heroines come. Rawiri, Ihimaera's narrator and Kahu's uncle, takes his mother on the back of his motorbike to fetch Kahu's pita or umbilical cord. Dressed in her formal black clothes and his Headhunter's jacket, the old lady races down Peel Street shocking her 
contemporaries, who when they see her through the blue smoke, almost swallow their false teeth' (2002, p.26). These vibrant details of contemporary life are equally vivid in Duiker's novel where Nolitye moves through busy streets:

\begin{abstract}
Mamani is back, selling roasted mealies. The traveling barber is still cutting hair. He is trimming a young man's hair. On a small clearing nearby some boys are playing marbles and some elderly men are sitting on the stoep drinking umqombothi, which they've bought from the take-away shop next door. But they're not drinking the real stuff, traditionally brewed sorghum beer. The umqombothi they are drinking is brewed in a factory and sold in cartons. The olderneighbourhood boys say that anyone who drinks it and isn't used to it will be drunk for days. The men don't seem drunk, Bheki thinks, just very pleased with themselves.

(Duiker 2006, p.63)
\end{abstract}

By setting their novels so unequivocally in the present, both Duiker and Ihimaera generate the delighted and unexpected thrill of recognition which comes from evoking the African or Maori child's marginalised reality within the pages of a novel, the literary property of a very different culture. Their detailed realism also powerfully evokes the sense of community, which Umelo Ojinmah suggests in his comparison of the writings of Ihimaera and Achebe (1993) is so much part of both African and Maori awareness.

By lovingly creating a world which is continuous with their readers' experience, they also ensure that, when figures of African or Maori myth emerge into it, they are less likely to be dismissed as old-fashioned remnants of a dated tribal consciousness. Readers who have empathised with Kahu's pain when her beloved grandfather misses the break-up ceremony at which she delivers a speech (Ihimaera 2002, p.85) or with Nolitye's rushed attempt to finish her Mathematics homework before the candle burns out (Duiker 2006, p.12) will be more willing to suspend disbelief when a whale with a sacred sign on its head beaches itself and begins to speak to Kahu (Ihimaera 2002, p.127) or Nomakhosi, the spirit of the stone dressed in the 'black-braided white skirt and wrap of a Xhosa woman', materialises in Nolitye's shack (Duiker 2006, p.82).
Within the contemporary contexts of these girls' lives, Koro Apirana, Kahu's grandfather, and Nomakhosi, the spirit of the stone, become defenders of a neglected past. Each acknowledges the problems besetting the girls' communities and each evokes an image of a golden age destroyed by human arrogance and greed. Thus Nomakhosi tells Nolitye of a lost world in which the tribes fulfilled the intentions of Nkulunkulu, the maker, until Ncityana, the unmaker, driven by ambition, sowed discord by first stealing and then shattering the stone which held the world in harmonious balance (Duiker 2006, p.83). The result is a world in which the tribes have been dispossessed of their spiritual link to the land and its creatures so that, at one stage, when Nolitye is told to follow the Healer of the Road who will lead her to where she needs to go, she is completely baffled:

'The healer of the Road?'

Noka, looking incredulous, says, 'My, my, you didn't know? It is Nqonqothwane, of course. Dung beetle is the Healer of the Road.'

Thembi apologetically pulls up her shoulders and explains: 'She grew up in a township.'

'I can't believe there are places where children grow up without knowledge of the Healer of the Road,' Noka says. 'But never mind. All the better that you have learned something new, child. The road holds many lessons.'

(Duiker 2006, p.212)

Ihimaera, on the other hand, cleverly allows Koro Apirana to anticipate potential reader scepticism when he reminds the boys of his family that man has driven a wedge through the original oneness of the world:

In the passing of Time he divided the world into that half he could believe in and that half he could not believe in. The real and the unreal. The natural and the supernatural. The present and the past. The scientific and the fantastic. He put a barrier between both worlds and everything on his side was called rational and everything on the other side was called irrational. 'Belief in our Maori Gods, 'he emphasized, has often been considered irrational.'

(Ihimaera 2002, p.115) 
Of course, for a contemporary reader, Koro Apirana's language, with its determined stress on the masculine pronoun, subtly undermines his utopian vision. The liminal status of Duiker and Ihimaera means that neither is capable of unthinkingly endorsing every aspect of their marginalised culture. Their rejection of traditional gender roles is nowhere more apparent than in the fact that both choose to put pre-pubescent girls at the centre of their novels. Their choices are particularly significant in a context in which, as Van Wyk Smith reminds us, the colonial discourse of domination ensures that 'land, indigene and woman are so often transformations of one another' (1990, p.55).

Ironically, Kahu and Nolitye challenge both the sexist assumptions of Maori and African tradition and the equally male-dominated narrative patterns of fantasy itself. Coming of age is central to almost all fantasies since the tale of a young hero's 'displacement, transformation and return' is, as Attebery suggests, 'the fundamental pattern of both the hero monomyth, as described by Joseph Campbell, and of the fairy tale as analyzed by Vladimir Propp' (1992, p.87). Both Nolitye and Kahu undergo just such a process as they move from the shifting potentialities of childhood towards individuation and the creation of a relatively stable adult identity. In considering the fact that traditional rites of passage are often focused on male rituals rather than the subtler and less public processes of female initiation, Attebery indicates that narratives of female coming of age may be shaped by the search for an acceptable maternal model. He justifies this claim by arguing that women need to add knowledge of individuality and rebellion to their inherent knowledge of continuity, duty and the submersion of the self if they are not simply to repeat the lives of their mothers and grandmothers (1992, p.100).

Eleven-year-old Nolitye's initial immaturity is shown by Duiker's emphasis on her close relationship with her mother, Thembi. The two share a single bed and this physical closeness is emblematic of Nolitye's dependency. However, finding the heart of the stone leads Nolitye to Nomakhosi, 'the Spirit of Women's Strength' (Duiker 2006, p.82). By giving Nolitye an affirming adult role model, Nomakhosi helps the young girl to take the first crucial steps on the journey to adult autonomy. Similarly, Kahu, while always valuing her grandmother, is never content to model herself on the older woman, yearning instead to be accepted as an equal by her rigidly conservative grandfather, who states categorically that, as a girl, she is 'of no use to me' (Ihimaera 2002, p.82).

By descending into watery and womb-like underworlds, Kahu riding on a whale and Nolitye following the call of Noka, the Queen of the River Spirits, the girls make possible a symbolic rebirth for both themselves and the peoples they represent. This descent also clearly leads them into a variant of what Northrop Frye calls the 'night world, often a dark and labyrinthine world of caves and shadows where the forest has turned subterranean, and where we are surrounded by the shapes of animals.' If the meandering and descent patterns of Paleolithic caves, along with the paintings on their walls, have anything like the same kind of significance, Frye argues, 'we are here retracing what are, so far as we know, the oldest imaginative steps of humanity' (1976, pp.111-112).

Empowered by this magical descent into the spirit world, Nolitye is then able to draw her father from his imprisonment within the rigid trunk of a baobab (Duiker 2006, p.229) while Kahu enables her grandfather to escape from his imprisonment within a world of equally constricting gender norms and awake to the realisation that 'Boy or girl, it doesn't matter' (Ihimaera 2002, p.147).

Ultimately then, both children show young readers how to reassess not only the material values which dominate their societies but also the cultural norms of the past. By refusing either to abandon the mythologies they have inherited or to preserve them artificially by writing pre-colonial pastoral, Duiker and Ihimaera ensure that their liberating fantasies point the way to new futures where Kahu 'may claim the place for her people in the world' (Ihimaera 2002, p.145) and Nolitye comes to realise that she has missed Phola 'because it is home. And home is never far away when you believe in it' (Duiker 2006, p.233).

Thus, by writing what Attebery describes as fully-realised indigenous fantasy, 'fantasy that is, like an indigenous species, adapted to and reflective of its native environment' (1992, p.129), both writers bring something new to contemporary children's fantasy. Each opens multiple 
doors not only between reality and fantasy but between past and present, tradition and innovation, coloniser and colonised, thus conjuring up a third space ' in which young readers can find alternative ways to understand who they are, where they are and, perhaps most importantly of all, where they want to be.

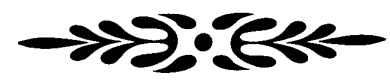

\section{REFERENCES}

Attebery, B. 1992. Strategies of fantasy. Bloomington: Indiana University Press.

Bettelheim, B. 1976. The uses of enchantment: the meaning and importance of fairy tales. Harmondsworth: Penguin.

Bhabha, H. 1994. The location of culture. New York: Routledge.

Corbalis, R. \& Garnett, S. 1984. Introducing Witi Ihimaera. Auckland: Longman Paul.

Duiker, K. 2000. Thirteen cents. Roggebaai: Kwela.

Duiker, K. 2001. The quiet violence of dreams. Roggebaai: Umuzi.

Duiker, K. 2006. The hidden star. Roggebaai: Umuzi.

Dunston, C. 2001. With many voices. The Mail \& Guardian: Friday, 10-16 August, 1 \& 3.

Gaiman, N. 2004. American gods. London: Headline.

Ihimaera, W. 2002 [1987]. The whale rider. Auckland: Reed.

Le Guin, U. 1976. The language of the night: essays on fantasy and science fiction. London: The Women's Press.

Luthi, M. 1986. The European folktale: form and nature. (J. Niles, Trans.). Bloomington: Indiana University Press.

McGlathery, J. (Ed.). 1988. The Brothers Grimm and folktale. Chicago: University of Illinois Press.
Mzamane, M. (Ed.). 2005. Words gone too soon: a tribute to Phaswane Mpe and K. Sello Duiker. Pretoria: Umgangatho.

Nesbit, E. 1979 [1902] Five children and it. London: Octopus.

Ojinmah, U. 1993. Witi Ihimaera: a changing vision. Te Whenwa Series, No 7. Pacific people land and literature. Dunedin: University of Otago Press.

Pullman, P. 1998. The subtle knife. London: Scholastic.

Propp, V. 1979. Morphology of the folktale. (L. Scott, Trans.). Austin: University of Texas Press.

Rohrich, L. 1988. The quest of meaning in folk narrative research. In J. McGlathery (Ed.), The Brothers Grimm and folktale. Chicago: University of Illinois Press, 1-15.

Rossouw, R. 2007. Harry Potter and the not that interested South Africans. The weekender, 21-22 June: 9.

Spufford, F. 2002. The child that books built. London: Faber \& Faber.

Smith, M. 1990. Grounds of contest. Cape Town: Juta.

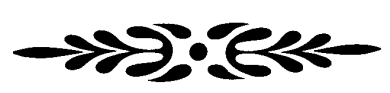

\section{BIOGRAPHICAL NOTE}

Molly Brown grew up on an isolated farm in the Eastern Cape where she was exposed to Xhosa folklore from an early age. She is currently a senior lecturer in the Department of English Language and Literature at the University of Pretoria and her primary research interest is in fantasy whether written for adults or children.

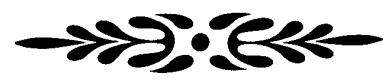

